\title{
Learning "Betwixt and Between": Opportunities and Challenges for Student-Driven Partnership
}

\author{
*Susanna Barrineau, Unit for Academic Teaching and Learning, Uppsala University, Sweden
} Lakin Anderson, Department of Business Studies, Uppsala University, Sweden

Contact: susanna.barrineau@uadm.uu.se

\section{ABSTRACT}

This paper analyses students' experiences of a partnership learning community in which students take on an unusual amount of power over decision-making in the design and implementation of interdisciplinary education. Student-driven contexts are largely absent in literature on partnership in higher education, which has thus far been based on empirical study of institutional contexts in which faculty have more power than students. This reveals a gap in knowledge about arrangements in which students have more control over decision-making than faculty. Drawing from indepth interviews with student course coordinators, and using the concepts of roles and liminality, we analyse how course coordinators perceive their challenging and often ambiguous roles in which they renegotiate their relationships to staff, students, and the university itself. We then identify some challenges and opportunities for partnership within this context.

\section{KEYWORDS}

partnership, roles, student-driven, liminality, education for sustainable development

Partnerships that position students-as-partners, co-creators, producers, and change agents in higher education (HE) have been shown to challenge university norms and hierarchies (Dunne \& Zandstra, 2011; Healey, Flint, \& Harrington, 2014; Cook-Sather, Bovill, \& Felten, 2014; Iversen, Pedersen, Krogh, \& Jensen, 2015), raise awareness about and even reshape student and staff roles and identities in a variety of contexts (Healey, 2017), and invite reflection on the value of $\mathrm{HE}$ and the inadequacy of treating it as a consumer product (Dunne \& Zandstra, 2011; Gärdebo \& Wiggberg, 2012; Sveriges förenade studentkårer, 2013; Bryson, 2014; National Union of Students, 2015). Partnership reshapes student and staff roles and leads to new types of relationships and processes that fundamentally change teaching and learning environments (Cook-Sather et al., 2014; Bovill, 2014; Bovill, CookSather, Felten, Millard \& Moore-Cherry, 2016).

Healey et al. (2014) argue that in order to realise the transformative potential of partnership in $\mathrm{HE}$, better understandings of how partnership works in theory and practice 
are needed. They define partnership as:

a process of student engagement, understood as staff and students learning and working together to foster engaged student learning and engaging learning and teaching enhancement. In this sense partnership is a relationship in which all participants are actively engaged in and stand to gain from the process of learning and working together. (p. 7)

Partnership is further characterised by the presence of certain values: authenticity, inclusivity, trust, empowerment, reciprocity, challenge, community, and responsibility (Healey et al., 2014). Students actively participate in activities that are usually only accessible to staff members, like curriculum design or the scholarship of teaching and learning and, therefore, partnership arrangements offer benefits that are co-created and not accessible to students or staff alone.

Studies of partnership have commonly been carried out in institutional contexts in which faculty have more power over decision-making and invite students to become partners (see Healey et al., 2014). In contrast, in this study we analyse what happens in a case when students have more power over decision-making in a student-driven educational context. Here students take on the responsibility of planning and coordinating university courses and inviting faculty to support them, an arrangement about which little is known from a HE partnership perspective.

In the context of ongoing partnership research, and using concepts of roles and liminality, our aim is to analyse and explain some consequences of this particular studentdriven educational context for student-faculty partnership in theory and practice. Liminality, which we clarify further below, refers to a state of being which is "in between." Our research question is What are the possibilities and challenges for student-faculty partnership in a student-driven educational context?

\section{A CENTRE FOR STUDENT-DRIVEN EDUCATION}

The Centre for Environment and Development Studies (CEMUS) is a joint centre at Uppsala University and the Swedish University of Agricultural Sciences. It breaks with institutional and educational norms of $\mathrm{HE}$ in its inter- and trans-disciplinary approaches to sustainable development and its student-driven educational model. CEMUS originated in 1992 when two students at Uppsala University became dissatisfied with the lack of educational focus on large-scale environment and development problems facing humanity. They developed a detailed plan for a seminar series course called "Man and Nature" (Människan och Naturen) that would draw together experts from across Sweden. With the help of a few supportive professors, they made repeated efforts to get the university to organise and offer the course. It was eventually approved, but there was a twist: because they had already planned the course in such detail, and because no department was interested in running it, the students themselves would be responsible for it. With a small budget directly from the vice chancellor's office, no faculty or departmental ownership of their project, and a loaned desk in the corner of Professor Hans Rosling's office, they began calling lecturers.

Almost 500 students applied to the first course, of which only 200 could be accepted due to room restrictions. From this beginning, CEMUS has developed and expanded, eventually becoming a university centre in 1997 that today offers 22 courses and manages 
ongoing activities in outreach and research. The organisation has retained the initial student-driven model, employing students to design, plan, and coordinate interdisciplinary courses for-credit at the undergraduate and graduate level that explore social, economic, and ecological sustainability questions and challenges. Courses continue to integrate researchers, lecturers, experts, and practitioners in a variety of disciplines and fields from across Sweden and abroad.

Two course coordinators (CCS) are hired to work on each course (i.e., a module or subject in some countries) on a nine-month project basis, with the possibility of continuing their position for up to three years. Coordinator positions are advertised publicly and are open to all students attending the two universities at which CEMUS is based. Most students hired as CCs have previously studied at CEMUS.

A core team of five permanent staff, all formerly CCs, provide organisational support, continuity, and representation for CEMUS. The CC pair is also supported in the course planning phase by a course-specific work group comprised of three to eight people and can include teachers, researchers, students who completed the course, external experts from the field, two core team members, and the CC pair. The work group provides critical feedback on assessment, assigned literature, pedagogical methods, and other course development topics.

Coordinators, with the already mentioned support people and routines, are responsible for planning and implementing seminars and active workshops and preparing assignments and examination tasks. They invite a series of guest lecturers, communicate with them about the course, and facilitate when lecturers are present. Literature for courses is compiled by coordinators, guest lecturers, and the work group and is then officially approved by the work group. Official course goals are set through formal university procedures; however, each iteration of a course is shaped significantly by those collaborating in its running - the attending students, the CC pair, the work group, and guest lecturers. Throughout course implementation, coordinators function as connectors, helping students tie together often diverse course material over the course duration and being a constant presence. It is also important to note that though the CCs are responsible for running courses, the pedagogical approach at CEMUS aims to put students enrolled in the courses in situations where they participate in and co-create learning, often allowing them to "take over" the classroom (Stoddard, Rieser, Andersson, \& Friman, 2012). Deeper study of CEMUS's pedagogical philosophy and student-centred pedagogical methods cannot be covered in this paper, but could be a suitable empirical context for future research on partnership and sustainability in $\mathrm{HE}$.

In pursuit of "contributing to a more sustainable and equitable world" (Hald, 2011, p. 12), CEMUS aims to embody the idea that "students are not simply subordinate consumers of knowledge, but rather intellectual equals and producers of knowledge" (Stoddard et al., 2012). The growth and persistence of this model over 25 years invites reflection on assumptions about the organisation of education, responsibilities and capacities of learners and teachers in $\mathrm{HE}$, and the how and what of student-faculty partnership.

\section{ROLES, UNCERTAINTY, AND STUDENT CONTROL IN PARTNERSHIP}

Healey et al. (2014) provide an extensive collection of cases of partnership predominantly from the UK and US. Where partnership has gone beyond discrete projects, partnership learning communities (PLCs), in which partnership becomes embedded in the culture and ethos of an institution, may be formed. These communities: 
invite critical reflection on existing relationships, identities, processes and structures and can potentially lead to the transformation of learning experiences. Given that partnership is both a working and learning relationship, these new communities should acknowledge the dual role of staff and students as both scholars and colleagues engaged in a process of learning and inquiry. (Healey et al., 2014, p. 8)

In this way, PLCs have an established collaborative culture where working in partnership is agreed upon as a foundation for learning, teaching, and even scholarship.

Much of what we see in partnership literature involves faculty inviting students into collaborative relationships, rather than students inviting faculty members. Faculty are the gatekeepers of curricula creation and exercise a high degree of control over providing students opportunities to work with learning and teaching processes (Bovill, 2014; Bovill et al., 2016). Fielding (1999), on the other hand, offers a more contentious vision of partnership, in which collegiality is radically inclusive and role boundaries are less securely drawn. However, we see a gap in knowledge about situations in which students are the instigators and/or leaders of a partnership relationship or learning community.

Student-faculty partnership is rooted in certain principles that are distinct from traditional practices in HE. These include the belief that (a) students have perspectives that can improve learning and teaching; (b) faculty can bring student insights into play by collaboratively designing learning and teaching; and (c) working in partnership can alter the way we see roles within $\mathrm{HE}$, making those involved better learners and teachers (CookSather et al., 2014).

Drawing on examples from the UK, Bovill (2014) outlines cases in which staff, who often feel unprepared for these types of partnerships, view their roles in the co-creation of curricula with students as risky. Bovill (2014) also notes that while working towards partnership does not erase the importance of the expertise of the staff members, it does change the role of staff towards becoming a "facilitator of learning" (p. 22). These types of roles that staff and students adopt in partnership relationships are often accompanied by uncertainties and shifts in power that lead to challenges with co-creating learning and teaching environments (Bovill et al., 2016; Barrineau, Schnaas, Engström, \& Härlin, 2016). Inspired by Sherry Arnstein's (1969) ladder of citizen participation, ${ }^{1}$ Bovill and Bulley (2011) illustrate a spectrum of student participation in curriculum design, which is presented in Figure 1. Bovill and Bulley's ladder of student participation in curriculum design is not intended to indicate any ideal level of participation, but as a tool to discuss relationships of power and decision-making alongside partnership processes. For example, it can prompt reflection on what kind of institutional support partnerships where students are in control require or what the pedagogical benefits would be if students were part of negotiating curricula. We address these points further in our discussion below.

\footnotetext{
${ }^{1}$ Arnstein's (1969) ladder illustrates eight "rungs" that correspond to the amount of citizen power and participation in decision-making processes. 
Figure 1: Ladder of student participation in curriculum design

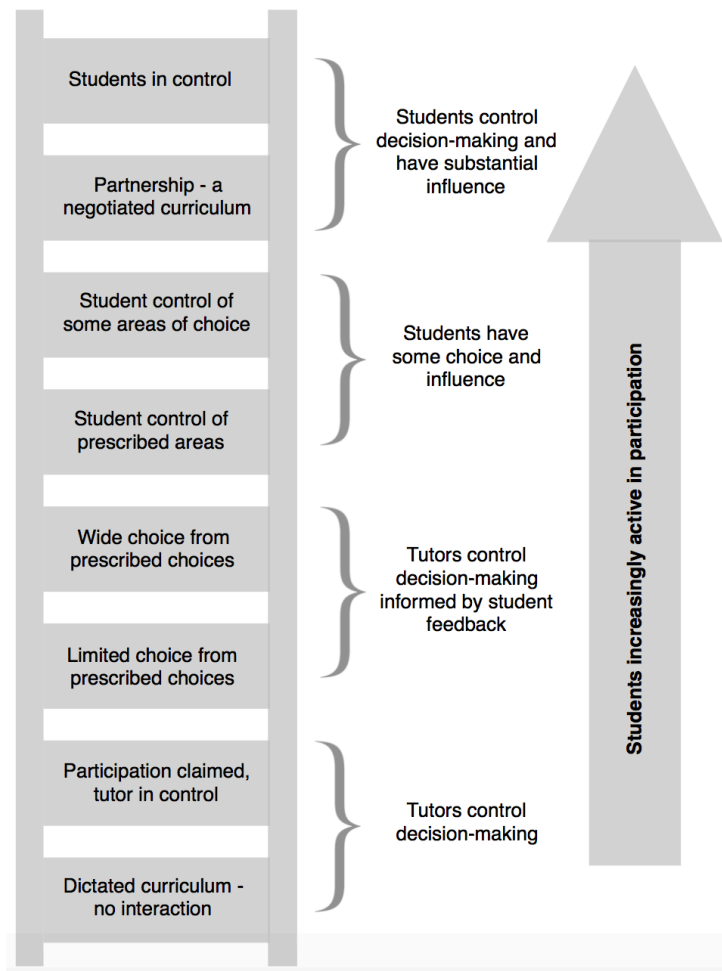

Figure 1: Source: Bovill \& Bulley, 2011, p. 181)

Peer-learning is another teaching and learning situation in which partnership can happen, and arguably falls more towards the "students-in-control" end of the ladder. Peerlearning "involves people from similar social groupings who are not professional teachers helping each other to learn and learning themselves by so doing" (Topping, 2005, p. 631). Students take on roles such as facilitator, tutor, teacher, and so forth, lead activities for their peers, and support each other in their learning (see, for example, Boud, Cohen, \& Sampson, 2001; Topping, 2005). In these situations, "students often have significant scope for negotiating the content and nature of the activity, and the students take on elements of the role of teachers or assessors of learning" (Healey et al., 2014, p. 13).

\section{LIMINALITY}

Changing or altering roles in partnership can be accompanied by discomfort and seen as risky because the "safe" and predictable path of education is withdrawn (Bovill et al., 2016; Felder \& Brent, 1996). Studies of partnership have shown that feelings of uncertainty and ambiguity around roles and responsibilities have been a key part of the practice of partnership itself. The anthropological concept of liminality helps in explaining how such new arrangements simultaneously offer uncertainty and possibility. Liminality refers to a state of being that is "betwixt and between" (Turner, 1967), a state of being outside of and between the fixed categories of a socially agreed upon structure or set of categories, which is therefore an ambiguous and undefined state. A person in a liminal state experiences both the death of structural identity and a resulting birth of possibility, entering a realm that can lead to new combinations of ideas and relations (Turner, 1967).

For example, Cook-Sather and Alter (2011) studied what happened when students were placed in a new role somewhere between student and teacher, a role not previously found at their institutions. Students experienced a sustained, "suspended state of liminality" 
(Cook-Sather \& Alter, 2011, p. 39) as they renegotiated their relationships with teachers, other students, and within learning in HE. This offered "a quality of experience with unique potential to challenge deep-seated assumptions about how a community or society works" (Cook-Sather \& Alter, 2011, p. 37). In the context of student-faculty partnership in HE, this may include, for example, challenging assumptions about power dynamics, roles of students and teachers, and responsibilities for learning.

Whereas Turner (1967) studied cases of liminality in rituals in which people transition from one fixed social category to another (for example, from child to adult), in this article we emphasise the experience of occupying a liminal position rather than the experience of liminality as a part of a transition. In this case, we look at the experience of being a course coordinator as occupying a liminal position.

\section{SUSTAINABILITY IN HIGHER EDUCATION}

Sustainable development challenges universities to rethink their approaches to research, education, outreach, and campus operations (Barth, 2014; Cortese, 2003; Lozano, 2006; Sterling, 2001;). Education for sustainable development (ESD) makes demands of HE that require changes in culture, teaching methods, curricula (Wals \& Corcoran, 2006; Wals, 2012), and also require finding ways of teaching students key competencies for sustainability (Wiek, Withycome, \& Redman, 2011). Research has shown a weak culture of collaboration between students and faculty, both within and across disciplines, to be a key stumbling block for efforts at embedding sustainability at universities (Krizek, Newport, White, \& Townsend 2012). Authors have highlighted the importance of new norm creation at the local level (Wickenberg, 2006) and engaging participants from across disciplines in neutral spaces not owned by a university department (Holmberg, Lundqvist, Svanström, \& Arehag 2012). Bottom-up approaches have been shown to be effective in developing and enhancing sustainable development education at universities. Distributing leadership to smaller communities of practice (see Wenger, 1999) within and across universities has effectively generated educational programs for sustainability and climate-related issues (Davison et al., 2013). Furthermore, programs and courses in ESD that are student-driven can allow lead students to develop "key competencies beyond the regular curricula" and create conditions for innovation and teaching and learning (Singer-Brodowski \& Bever, 2016). Analysing the benefits and challenges of student-faculty partnership and PLCs in HE may thus be particularly relevant for student-driven, bottom-up, sustainability-focused educational contexts.

\section{PARTICIPANTS AND METHODS}

We conducted ten semi-structured interviews with employees at CEMUS in December 2015 (see Appendix 1). Each employee that we interviewed has worked as a CC from 9 months to 3 years with the exception of one long-term employee who has worked at CEMUS for 8 years, originally starting as a CC. Interviewees voluntarily joined the research based on interest by responding to an inquiry via email. Semi-structured interviews allowed for the researchers to focus each interview on particular areas but also to probe deeper into certain themes as they arose.

Each interview lasted 60-80 minutes and was conducted in English. Interviewees were asked predetermined questions covering four key areas: (a) How do interviewees define their role; are they students, teachers, something else?; (b) What do they see as their main tasks and responsibilities?; (c) Do they see themselves as acting in partnership or 
collaborating with other actors, and if so, who?; and (d) Do they see their or CEMUS's work as having an effect on the wider university context and if so, how? We did not provide interviewees with a definition for or verbal elaboration of partnership. This was done to avoid setting boundaries for interviewee's possible interpretations.

Interviews were fully transcribed and then coded using TAMS coding software. To sort data, an exploratory coding method was used to link provisional codes to the research questions. Our codes were "roles," "responsibilities," "collaboration," and "wider university." We then further used in-vivo coding to identify common native terms and expressions used across interviews. We continued with thematic analysis following Patton (2002) and identified main themes: ambiguity over roles, working in partnerhip (partnership), liminality, and inviting faculty.

This study gathers data of the experiences of one particular group of people, based on their personal experiences and interpretations, while also relating to the organisational context. Other important voices could be those of guest lecturers, students, or administrators. This is therefore a limited study of a complex and unusual learning context. We reason that as the $C C$ is an unusual role, and central to the educational model under study, a more focused examination of that role is a productive place to start. CEMUS is a constantly evolving community with a practice regularly passed on through generations of CCs, lecturers, students, and others involved in the community. The experiences of these CCs are particular and therefore not necessarily generalisable to CEMUS's 25-year development. Interviewees had widely varied employment lengths and activities, and so interview data reflects a comprehensive picture of lived experience at CEMUS. A further limitation is that interviews were conducted several months after the collaborative course planning phase. This length of time may have affected interviewee's perceptions of their collaborations and relationships with different actors.

\section{THE EXPERIENCE OF BEING A STUDENT COURSE COORDINATOR}

Here we present results from the interviews. We raise three main areas for analysis: (a) using multiple terms for ambiguous roles, (b) the course coordinators' experiences of being uncertain of one's own legitimacy while at the same time being empowered, and (c) the course coordinators' perceptions of their weak relationships with faculty, despite relying on them and working with them often. Later we analyse these themes in relation to our research question and identify some opportunities and challenges for partnership that accompany a student-driven educational model.

\section{Ambiguity over roles: Not teachers, not experts, not easy}

Course Coordinators co-produce learning and teaching, while at the same time inhabiting an ambiguous role that lies outside institutional norms. All interviewees said they had difficulty describing their role(s) - what they actually do-to the students taking their course, to university faculty, and to others. Interviewees used a variety of descriptive terms:

- student

- connector

- responsible participant

- pedagogue

- not-a-teacher

- co-student
- facilitator

- educator

- leader

- learner

- meta-person

- master of puppets 
Coordinators found the role ambiguous. For example, one participant stated that students "don't necessarily see me in the same way that they see other teachers. So, it's floating around, it's undefined" (Interview 4). Many said that in discussion with others, any descriptive term or label like "CC" was inadequate and needed to be followed by a longer description of activities that the role actually required. Multiple CCs said they therefore relied on the students taking the course to understand the role of the CC implicitly through the way the coordinator ran the course.

A majority of CCs saw themselves as facilitators of some kind, something "between teacher and student," or a "co-student," but all saw themselves as students and as participants in the class in a way that teachers were not:

I saw my role as sort of, partly a facilitator, partly somebody providing some sort of framework for the students to be able to work through the course. So, being a constant-as we had all these guest lectures-being somebody that was there the whole time. And I think it was sort of being between student and teacher. (Interview 5)

This ambiguity led to feelings of uncertainty about how others perceive them and what is expected of them:

I don't think there is a universal understanding of who I am in the room and what I am supposed to do from, like, all the different students. Some are like "they're tutors" and some are "they're teachers," and some "they're like coordinators" and so I think that that's what forces you into that position. . . . It's like well, what am I going to do now? (Interview 3)

At the same time, this ambiguity of the CC role offered the freedom to be experimental and risk failure, while being "willing to try things, which don't always work" (Interview 4), which contrasted with "teachers," who CCs believed were less likely to experiment in this way.

Most CCs actively resisted being called teachers in the classroom by students or guest lecturers, saying that it was important they define themselves as not experts in the subject matter of the course or in teaching; nor were they authority figures: "as soon as they say I am a teacher or anything like that I say 'no, I am a facilitator.' I try to break that down and say 'no, I am a normal person'" (Interview 6). Almost all coordinators interviewed stressed the idea that "we are not the ones who have the right answers" (Interview 10). Some commented that avoiding the teacher/expert role took the pressure to "know everything" (Interview 4) off their shoulders: "if you say you are not the teacher, it's ok to say 'I don't know'" (Interview 10). This gave CCs more credibility and confidence in being not teachers or experts, and thus placing more responsibility for learning on the students themselves, rather than on the "experts in charge." This still left them in constant doubt over what their role was, however. One interviewee answered the following when asked how he described his role to students:

I think it is very difficult. Because it doesn't exist, maybe. . . It is hard to communicate and make the students grasp what we are, actually. That's the reason it is defined implicitly. Because it is not a clearly defined role. Because we have too much responsibility [to be] a student, and too little [to be] a teacher or professor. Or 
too little official knowledge to be a professor, or too little formal education to actually do what we are doing. And I think through that, it is unclear what we are actually. ... This is an issue. At the same time this is the beauty. (Interview 4)

Coordinators further expressed two seemingly conflicting views about legitimacy. Coordinators often felt underqualified or that they were doing something they should not be doing. Newer coordinators in particular also often felt ill-equipped to meet these high expectations: "I think there's this expectation that we're gonna maintain a certain environment for them but that is not really very easy without tools that I'm not sure I have" (Interview 5).

At the same time, coordinators felt empowered, confident they were doing something meaningful, and that they had freedom to do education differently and to improve on the education they themselves had experienced. One participant elaborated on the CC's responsibilities in the classroom setting:

Being a good pedagogue. Trying to offer a good education that is not just doing the same thing people have already been doing in their studies. Trying to break away from some structures that we know are dominating conventional academia. Using alternative tools and trying to provide students more freedom and space for manoeuvring themselves. (Interview 7)

CCs aimed to move beyond "this type of education where someone just tells you what to do and you do it" (Interview 8) and placed students more at the centre of education.

\section{Partnership}

Coordinators did not necessarily see themselves as working closely with faculty members. From the perspectives of CCs, the community at CEMUS consisted mostly of themselves and students taking courses, despite the yearly engagement of 100-200 guest lecturers and at least 30 work group members. Collaborations between CCs and various faculty members were often short but instrumental, and inviting guest lecturers did not necessarily result in meaningful work relationships: "you just extract a bit of knowledge from this place or this place and inject it into a CEMUS course and they leave again. Apart from having them for lectures, there's not much contact" (Interview 2).

At the same time, CCs described the faculty and external experts in course work groups as a valuable point of collaboration with the university. Coordinators' relationships to work group members were varied, some describing the work groups as a valuable meeting with colleagues and partners, others as a mandatory formal meeting with minimal results.

Many CCs had also built professional relationships with certain guest lecturers, who returned to particular courses each year and who over time formed ongoing relationships with the course and the student groups. In addition, CCs perceived positive benefits for many guest lecturers in their interactions with students in CEMUS courses:

Lecturers coming in here, we talk to them about CEMUS, they engage with different discourses and different students, we have interdisciplinary classes. They get questions they didn't get before, they are able to communicate about things they can't communicate about in another setting. They engage in a different way, we 
leave it open to them, we support them in using different methods. I think all of that has an impact on the university. (Interview 4)

Still, CCs spoke often about being "in a bubble," a phrase that reappeared in many interviews. They felt isolated in terms of ties and influences within the wider university and felt that their work was distinct from the faculty and other departments and centres. Many interviewees thought that such collaboration needed to be improved.

However, some CCs perceived their work as engaging with the wider university through the students in their courses, who were enrolled in a variety of programs and disciplines. Furthermore, CCs developed strong reciprocal learning relationships with students in courses. One CC commented that the CC role provided "the chance to be more involved with the students ... and be part of their learning and it's also my learning" (Interview 10).

\section{DISCUSSION: POSSIBILITIES AND CHALLENGES FOR STUDENT-FACULTY PARTNERSHIP IN A STUDENT-DRIVEN EDUCATIONAL CONTEXT}

\section{Inhabiting liminal roles}

In the context of CEMUS education, the concept of liminality, and more specifically a "suspended state of liminality" (Cook-Sather \& Alter 2011, p. 39), helps us explain how students experience the $\mathrm{CC}$ role and furthermore, what a student-driven educational context can mean for partnership.

Both CEMUS as a centre and the $\mathrm{CC}$ as a position at the university fall outside of typical categories within HE. Similarly, coordinators occupy neither the roles of students nor university teachers, but instead "assume a position that is 'ambiguous, neither here nor there, betwixt and between all fixed points of classification"” (Turner, 1974, p. 232 as cited by Cook-Sather \& Alter, 2011, p. 37). This causes a loss of legitimacy due to "not fitting into the system," creating uncertainty over their role and responsibilities in the university and in the classroom. They can feel unqualified, unprepared, and unsure of the extent of what they can and cannot do. At the same time, they experience a sense of freedom, empowerment, and a possibility to "do education differently."

As Bovill et al. (2016) recognise, "The challenges staff and students experience in cocreating learning and teaching are sometimes related to very real concerns about boundaries, capabilities and risk" (p. 198). In practice, this results in different coordinators adopting a number of closely associated roles (e.g., co-student, facilitator, responsible participant, etc.) that mitigate their concerns with their own perceived capabilities and with the challenge of crossing traditional HE boundaries.

CEMUS and the coordinator role incorporate liminality into the university in a fruitful way. CEMUS is a student-driven, trans-disciplinary centre within a traditional university structured by discipline. The non-teacher, non-student CC position exists in an institutional context with clearly defined student-teacher roles and a lack of student-faculty partnership culture. This combination enables experimentation and for boundaries to be broken, inviting students, teachers, and experts to (re)consider and reinterpret the how and why of learning. This is key to enabling coordinators to differentiate what they do from what teachers do.

From this "betwixt and between" position, students have organised themselves in an advanced way to coordinate learning and teaching around complex questions and problems posed by sustainability challenges. Furthermore, they have done so in a way that exhibits an 
alternative power dynamic to that of the institution which surrounds them.

\section{Students inviting staff to participate in partnership}

CEMUS differs from other, well-documented forms of partnership because of the amount of power students have. We argue that CEMUS's educational model, managed and driven by "those traditionally regarded as the least able and least powerful members of the educational community" (Fielding, 1999, p. 21), is an example of a PLC that falls outside current conceptions of partnership in important ways.

This type of partnership arrangement moves outside the landscape of Healey et al.'s (2014) conceptual PLC model because of the students' level of control over decision-making. Referring back to Bovill and Bulley's (2011) ladder of student participation in Figure 1, CEMUS education arguably falls in the "students-in-control" end of the spectrum.

CEMUS does not refer to its educational model as a partnership model, but calls its work "student-driven education." However, it offers opportunities for actively engaging students and faculty to create learning spaces, as Healey et al. (2014) outline in their partnership definition, mentioned above. Already built into the CEMUS model is "the collaboration and mutual exchange between students and senior academics [which] confounds the old notion of researcher as teacher and examiner" (Stoddard et al., 2012). Staff are involved and do collaborate, but not necessarily as clear authority figures or leaders. Approaching CEMUS through a partnership lens consequently highlights the asymmetrical dimensions of some other partnership arrangements in which students can be invited in for short bursts to work together with teachers, similar to the way in which CCs invite teachers in as guests. The students' agency is thus different here, and this may have important consequences when considering the how and why of partnership. However, it is worth noting that, as Healey et al. (2014) and other authors in the partnership literature have shown, faculty-initiated partnership has potential to involve comparatively longer-term and more in-depth relationships. The same likely applies for student-initiated partnership.

Students inviting teachers to lecture and be work group members changes power dynamics, which invites agency and creates conditions to "re-learn [ways] of teaching and learning" (Wals \& Jickling, 2002, p. 228). At the same time, it is possible in this type of arrangement that students can also become gatekeepers, maintaining control over access and decision-making in a way that partnership was perhaps meant to rectify (a sort of toofar pendulum-swing). This leaves open the possibility of a partnership arrangement with a high level of student participation but reduced or minimal opportunity for staff to engage. As we move along Bovill and Bulley's (2011) ladder of student participation, increased student control of curricula does not necessarily increase the success of partnership. A very empowered student group might not enter into partnership fully, missing out on its benefits not only for themselves but for the university.

We see some signs of this in our empirical study. None of the CCs saw themselves as having strong relationships with guest lecturers in general since these were usually shallow interactions relative to other relationships with colleagues at CEMUS. Many CCs mentioned the value of faculty members in the course work groups, but they were seen as a rather limited resource in terms of time. This is not to say CCs did not value faculty involvement, but rather that the sustained relationship between students and faculty desired in partnership was often not reflected in interviewees' experiences. Coordinators felt that their individual relationship to many faculty members was, to borrow from Healey et al. (2014), not necessarily "a relationship in which all participants are actively engaged in and 
stand to gain from the process of learning and working together" (p. 7) or that it could be improved dramatically.

It is important to note that staff influence and involvement is routine and widespread at CEMUS, and this means that staff and students collaborate in a community quite unlike what is seen in the wider university context in which they are situated. In addition, the sheer number of guests visiting (100-200 per year) as guest lecturers or in CEMUS's extensive collaboration, outreach, and research activities, may have influenced CC perceptions of relationships to faculty. These many shallow interactions may lead CCs to feel they simply do not have the opportunity to work closely with faculty.

While the very existence of the CC role does invite "critical reflection on existing relationships, identities, processes and structures" (Healey et al., 2014, p. 7), the peer-topeer interactions in the form of relationships both between the coordinators and with students in their courses took a more central role than those involving CCs and faculty. Peerlearning (see Topping, 2005; Boud et al., 2001) characterises aspects of the CEMUS model, in the relationships between the coordinator pairs and by students taking on different roles in teaching and learning to facilitate learning. Faculty in the CEMUS context were viewed as information providers and as temporary experts, and coordinators expressed that many lecturers barely seem to understand the coordinator role. We see an opportunity here for coordinators and teachers to engage further with and develop partnerships in a learning community working from the unusual premise and institutional context of a centre for student-driven education.

A challenge for the CEMUS PLC may be ensuring that students do not become gatekeepers themselves, seeing university staff as those who are invited but not significant partners. Another related challenge is ensuring that relationships between engaged students and supportive and engaged faculty are continually renewed and created.

\section{Opportunities and challenges}

This study raises a number of opportunities and challenges to partnership in which students have more power over decision-making in key areas like curriculum design and learning and teaching in practice. We tentatively suggest some of these as summarised in the table below. 
Table 1. Opportunities and challenges of student-driven partnership arrangements and liminal roles

\begin{tabular}{|l|c|c|}
\hline \multicolumn{1}{|c|}{ CONTEXT } & OPPORTUNITIES & CHALLENGES \\
\hline $\begin{array}{l}\text { Students hold } \\
\text { balance of } \\
\text { power in } \\
\text { institutional } \\
\text { context }\end{array}$ & $\begin{array}{c}\text { - Students form a strong } \\
\text { community engaged in education in } \\
\text { formal and informal ways } \\
\text { - Faculty support and engage in } \\
\text { a learning and teaching } \\
\text { environment where they also learn } \\
\text {-A learner-centred, as opposed } \\
\text { to teacher-centred, approach is } \\
\text { enabled }\end{array}$ & $\begin{array}{c}\text { - Teachers can be excluded due } \\
\text { to students becoming gatekeepers } \\
\text { - Existing and new relationships } \\
\text { between students and faculty are } \\
\text { continually renewed and created }\end{array}$ \\
$\begin{array}{l}\text { Students' roles } \\
\text { located in a } \\
\text { "suspended } \\
\text { liminal state" }\end{array}$ & $\begin{array}{c}\text { - Students and teachers find } \\
\text { freedom of possibility for new } \\
\text { combinations, ideas, relationships } \\
\text { - Students' non-expert role } \\
\text { generates potential for alternative } \\
\text { power dynamics in the classroom }\end{array}$ & $\begin{array}{l}\text {-Students experience a } \\
\text { of fixed categories } \\
\text { - Students need support and } \\
\text { routines while dealing with } \\
\text { uncertainty } \\
\text { - Purpose or value of liminal roles } \\
\text { may not be clear or accessible to }\end{array}$ \\
& $\begin{array}{l}\text { those outside the learning } \\
\text { community and to actors who take } \\
\text { on the fixed roles within HE (e.g., } \\
\text { administrators, teachers, students) }\end{array}$ \\
\hline
\end{tabular}

\section{CONCLUSION: TOWARDS A BETTER UNDERSTANDING OF STUDENT-DRIVEN PARTNERSHIP} ARRANGEMENTS IN HE

Current conceptualisations of student-faculty partnership in HE commonly assume an institutional context in which faculty have the balance of authority and power over decision-making. Little is known about partnership arrangements in which it is students that have more power than faculty. This study has analysed the latter type of partnership, zooming in on the experiences of student CCs who manage design and implementation of sustainability education in a student-driven university centre. Our findings in this exploratory study are that this partnership arrangement (a) suggests revision or expansion of current notions of partnership to redress strong assumptions about staff having the balance of authority and power; (b) places students in an ambiguous role, a "suspended state of liminality," which, while confusing for them and others, also offers them freedom and possibilities to break with strong institutional norms about the how and why of education; and (c) has allowed students to creatively organise education at an advanced level. Further research could explore the relationship between student-driven models of partnership and the boundary-spanning nature of transdisciplinary sustainability education across disciplines and university structures.

This snapshot of CC perspectives is only one view of the education at CEMUS. The perspectives of students, lecturers, and external experts would be valuable contributions in future research. Additionally, learning outcomes, observation of classroom settings, and experimentation with the model in other contexts would all be worthy of further study. More generally, we see significant potential for further research into student-driven 
initiatives in $\mathrm{HE}$ that enter into the core functions of the university-education, research, and outreach-in order to increase knowledge about and experimentation with new forms of partnership.

This article accords with ethics standards for the Department of Earth Sciences, Uppsala University. All transcripts of interviews were validated in writing by interviewees.

\section{NOTE ON CONTRIBUTORS}

Susanna Barrineau works with the Continuous Development of Active Student Participation at the Unit for Academic Teaching and Learning at Uppsala University, and is a former course coordinator (2012-2015) at CEMUS.

Lakin Anderson is a $1^{\text {st }}$ year PhD Student in the Uppsala University Department of Business Studies' organisations research group. He researches how universities enable or disable bottom-up efforts to put sustainability into practice. He was a course coordinator at CEMUS between 2013-2016.

\section{REFERENCES}

Arnstein, S. R. (1969). A ladder of citizen participation. Journal of the American Planning Association, 35(4), 216-224.

Barrineau, S., Schnaas, U., Engström, A., \& Härlin, F. (2016). Breaking ground and building bridges: a critical reflection on student-faculty partnerships in academic development. International Journal for Academic Development, 21(1), 79-83.

Barth, M. (2014). Implementing sustainability in higher education: Learning in an age of transformation. London: Routledge.

Boud, D., Cohen, R., \& Sampson, J. (2001). Peer learning in higher education: Learning from and with each other. London: Kogan Page.

Bovill, C. (2014). An investigation of co-created curricula within higher education in the UK, Ireland, and the USA. Innovations in Education and Teaching International, 51(1), 1525.

Bovill, C., \& Bulley, C. J. (2011). A model of active student participation in curriculum design: Exploring desirability and possibility. In C. Rust (Ed.), Improving student learning (ISL) 18: Global theories and local practices: Institutional, disciplinary, and cultural variations (pp. 176-188). Oxford Brookes University: Oxford Centre for Staff and Learning Development.

Bovill, C., Cook-Sather, A., Felten, P., Millard, L., \& Moore-Cherry, N. (2016). Addressing potential challenges in co-creating learning and teaching: Overcoming resistance, navigating institutional norms, and ensuring inclusivity in student-staff partnerships. Higher Education, 71, 195-208.

Bryson, C. (2014). Understanding and developing student engagement. London and New York: Routledge.

Cook-Sather, A., \& Alter, Z. (2011). What is and what can be: How a liminal position can change learning and teaching in higher education. Anthropology \& Education Quarterly, 42(1), 37-53.

Cook-Sather, A., Bovill, C., \& Felten, P. (2014). Engaging students as partners in teaching and 
learning: A guide for faculty. San Francisco: Jossey-Bass.

Cortese, A. D. (2003). The critical role of higher education in creating a sustainable future. Planning for Higher Education, 31(3), 15-22.

Davison, A., Brown, P., Pharo, E., Warr, K., McGregor, H., Terkes, S., Boyd, D., \& Abuodha, P. (2013). Distributed leadership: Building capacity for interdisciplinary climate change teaching at four universities. International Journal of Sustainability in Higher Education, 15(1), 98-110.

Dunne, E., \& Zandstra, R. (2011). Students as change agents: new ways of engaging with learning and teaching in Higher Education. ESCalate, Bristol. Retrieved from http://escalate.ac.uk/8242.

Felder, R. M., \& Brent, R. (1996). Navigating the bumpy road to student-centered instruction. College Teaching, 44(2), 43-47.

Fielding, M. (1999). Radical collegiality: Affirming teaching as an inclusive professional practice. Australian Educational Researcher: A publication of the Australian Association for Research in Education, 26, 1-34.

Gärdebo, J., \& Wiggberg, M. (Eds.) (2012). Students, the university's unspent resource: Revolutionising higher education through active student participation. Report series 12, Division for Development of Teaching and Learning, Uppsala University.

Hald, M. (Ed.) (2011). Transcending boundaries: How CEMUS is changing how we teach, meet, and learn. Uppsala, Sweden: CEMUS, Uppsala Centre for Sustainable Development, Uppsala University and Swedish University of Agricultural Sciences.

Healey, M., Flint, A., \& Harrington, K. (2014). Engagement through partnership: Students as partners in learning and teaching in higher education. York: Higher Education Academy.

https://www.heacademy.ac.uk/system/files/resources/engagement_through_partn ership.pdf

Healey, M. (2017). Students as partners and change agents in learning and teaching in higher education. Retrieved from http://www.mickhealey.co.uk/resources

Iversen, A., Pedersen, A. S., Krogh, L., \& Jensen, A. A. (2015). Learning, leading, and letting go of control: Learner-led approaches in education. Sage Open, 5(4).

Holmberg, J., Lundqvist, U., Svanström, M., \& Arehag, M. (2012). The university and transformation towards sustainability: The strategy used at Chalmers University of Technology. International Journal of Sustainability in Higher Education, 13(3), 219231.

Krizek, K. J., Newport, D., White, J., \& Townsend, A. R. (2012). Higher education's sustainability imperative: How to practically respond? International Journal of Sustainability in Higher Education, 13(1), 19-33.

Lozano, R. (2006). Incorporation and institutionalization of SD into universities: Breaking through barriers to change. Journal of Cleaner Production, 14(9-11), 787-796.

National Union of Students (NUS) (2015). A manifesto for partnership. Retrieved from https://www.nusconnect.org.uk/resources/a-manifesto-for-partnership.

Patton, M. Q. (2002). Qualitative research and evaluation methods ( $3^{\text {rd }}$ ed.). Thousand Oaks, CA: Sage Publications.

Singer-Brodowski, M., \& Bever, H. (2016). At the bottom lines: Student initiatives for sustainable development in higher education. In L. Kruse (Ed.), Human ecology studies and higher education for sustainable development: European experiences and examples. Munich: oekm verlag. 
Sterling, S. (2001). Sustainable education: Revisioning learning and change. Totnes: UIT Cambridge Ltd.

Stoddard, I., Rieser, I., Andersson, S., \& Friman, E. (2012). Igniting a learning revolution: Student-run higher education for sustainable development. The Solutions Journal, 3(5), 34-39. Retrieved from https://www.thesolutionsjournal.com/article/ignitingalearning-revolution-student-run-higher-education-for-sustainable-development/

Sveriges förenade studentkårer (SFS) (2013). Studentens lärande i centrum. SFS om pedagogik i högskolan. Dnr: PU1-1/ 1213.

Topping, K. (2005). Trends in peer learning. Educational Psychology, 25(6), 631-645.

Turner, V. (1967). Betwixt-and-between: The liminal period in rites de passage. In V. Turner (Ed.), The forest of symbols: aspects of Ndembu ritual Ithaca (pp 46-55). NY: Cornell University Press.

Wals, A. (2012). Shaping the education of tomorrow: 2012 full-length report on the UN decade of education for sustainable development. UNESCO. Retrieved from http://library.wur.nl/WebQuery/wurpubs/fulltext/246667

Wals, A., \& Corcoran, P. B. (2006). Sustainability as an outcome of transformative learning. In E. B. Samuelsson \& J. Holmberg (Eds.), Drivers and barriers for implementing sustainable development in higher education (pp.103-108). Paris: UNESCO.

Wals, A., \& Jickling, B. (2002). "Sustainability" in higher education: From doublethink and newspeak to critical thinking and meaningful learning. International Journal of Sustainability in Higher Education, 3(3), 221-232.

Wenger, E. (1999). Communities of practice: Learning, meaning, and identity. Cambridge, U.K.: Cambridge University Press.

Wickenberg, P. (2006). Norm supporting actors and structures at the very local level of implementation of sustainable development in higher education. In E. B. Samuelsson, \& J. Holmberg (Eds.), Drivers and barriers for implementing sustainable development in higher education (pp. 109-119). Paris: UNESCO. Retrieved from http://erepository.uonbi.ac.ke/handle/11295/60357

Wiek, A., Withycombe, L., \& Redman, C. L. (2011). Key competencies in sustainability: A reference framework for academic program development. Sustainability Science, 6(2), 203-218.

APPENDIX 1

\begin{tabular}{|c|l|l|r|}
\hline Name & Position & $\begin{array}{l}\text { Time at } \\
\text { CEMUS }\end{array}$ & Date \\
\hline Interviewee 1 & $\begin{array}{l}\text { CC, The Global Economy: Environment, } \\
\text { Development and Globalisation }\end{array}$ & 9 months & 2015-12-12 \\
\hline Interviewee 2 & $\begin{array}{l}\text { CC, Climate Change Leadership: Power, } \\
\text { Politics and Culture }\end{array}$ & 1.5 years & 2015-12-07 \\
\hline Interviewee 3 & $\begin{array}{l}\text { CC, Critical Perspectives on Sustainable } \\
\text { Development in Sweden }\end{array}$ & 9 months & 2015-12-12 \\
\hline
\end{tabular}




\begin{tabular}{|c|c|c|c|}
\hline Interviewee 4 & $\begin{array}{l}\text { CC, Project Management and } \\
\text { Communication \& Worldviews Values } \\
\text { and Visions course in the MSc. } \\
\text { Sustainable Development Program }\end{array}$ & 3 years & 2015-12-14 \\
\hline Interviewee 5 & Director & 8 years & $2015-12-18$ \\
\hline Interviewee 6 & $\begin{array}{l}\text { CC, Klimatet och Energin och det } \\
\text { Moderna Samhället (Climate, Energy } \\
\text { and the Modern Society) }\end{array}$ & 9 months & 2015-12-01 \\
\hline Interviewee 7 & $\begin{array}{l}\text { CC, Livsfilosofi och det Moderna } \\
\text { Samhället (Philosophy of Life and the } \\
\text { Modern Society) }\end{array}$ & 5 years & $2015-12-18$ \\
\hline Interviewee 8 & $\begin{array}{l}\text { CC, Worldviews Values and Visions } \\
\text { course in the MSc. Sustainable } \\
\text { Development Program }\end{array}$ & 1.5 years & $2015-12-14$ \\
\hline Interviewee 9 & $\begin{array}{l}\text { CC, Sustainable Design: Ecology, } \\
\text { Culture and Human Built Worlds }\end{array}$ & 2 years & $2015-12-14$ \\
\hline Interviewee 10 & $\begin{array}{l}\text { CC, Hållbar Utveckling A (Sustainable } \\
\text { Development A) }\end{array}$ & 2 years & 2015-12-11 \\
\hline
\end{tabular}

